\title{
Review: Monika Domańska Implementacja dyrektyw unijnych przez sqdy krajowe (Implementation of EU Directives by National Courts), Warszawa 2014
}

The process of directive implementation does not end with the introduction of the contents of a given directive into the national legal order in a sufficiently clear and precise manner within the time limit prescribed in the directive (the normative aspect of transposition). On the contrary, it is a continuous process in which the objectives of the directive must be secured by full application of the provisions transposing the directive into national law by competent national authorities, including in particular national courts, and by the enforcement of these provisions where they are breached (the operational aspect). Advocate General L. A. Geelhoed aptly argues that the implementation process is not concluded with the correct transposition of the provisions of the directive and the establishment of the organisational framework for the application of these provisions, and it must also be ensured that these two aspects (i.e. the normative and operational aspects) operate in such a way as to achieve in practice the result sought by the directive. ${ }^{1}$ The Court of Justice of the EU formulates in a rather unambiguous way the obligations resting with the national authorities/courts: "the adoption of national measures correctly implementing a directive does not exhaust the effects of the directive. Member States remain bound actually to ensure full application of the directive even after the adoption of those measures."

1 Opinion of Advocate General L. A. Geelhoed of 26.4.2005 in case C-494/01, Commission of the European Communities v Ireland, ECLI:EU:C:2004:546.

2 See: Marks \& Spencer, case no C-62/00, judgment of 11.7.2002, ECLI:EU:C:2002:435. 
M. Domańska's monograph Implementacja dyrektyw unijnych przez sqdy krajowe (Implementation of EU Directives by National Courts) is the first monographic analysis of the issues in Polish literature related to the implementation of EU directives. The publication fills this hitherto gap splendidly. The practical value of this work is all the greater as the author does not focus solely on theoretical aspects (which, quite understandably, are also prominently featured in the book and constitute a solid point of departure for the ensuing considerations), but discusses practical problems emerging at the stage of court operationalization of directives, documenting her analysis with a wealth of carefully selected case law of courts of all instances (common and administrative courts as well as the Supreme Court and the Constitutional Tribunal).

The requirement to implement directives in the national legal order imposes a number of obligations upon national authorities. The author of the monograph focuses in her considerations on the classification of these obligations and discusses the responsibilities which rest with national courts and are related to the application of national provisions by the said courts within the scope of the regulations contained in EU directives. The courts adjudicating in cases falling within the scope of Union law are bound by a number of duties. They are obliged to apply mechanisms derived from Union law (particularly the ones stemming from the principle of sincere cooperation under Article 4 para. 3 TEU), which frequently modify the national mechanisms of law application.

The first chapter, entitled Implementacja dyrektyw - zagadnienia wstępne (Implementation of directives - preliminary problems), presents the theoretical aspects of the implementation of directives and identifies the basic problems related to the directive as an act of EU law requiring implementation into national legal systems. In this chapter, the author clarifies certain issues related to the terminology which is used in the literature on the subject, arguing quite rightly that the term implementation has a broader meaning than the term transposition. Moreover, she presents the normative grounds underlying the obligation of implementing directives, which is particularly important from the perspective of the operation of a court.

The second chapter, entitled Sqdy krajowe jako organy implementujace (National courts as the implementing authorities), is of key importance if we look at the title of the monograph. Thus chapter focuses on the essential role of national courts in the process of the implementation of directives in the operational aspect, i.e. related to the application of national provisions falling within the scope of directive regulations. The author identifies the 
legal grounds for the implementation of directives by courts and distinguishes the following among them: 1) the principle of primacy of EU law; 2) the principle of effectiveness of EU law and 3) the obligations derived from Article 288 pt. 3 TFEU in conjunction with Article 4 para. 3 TEU. The procedure of preliminary questions (Article 267 TFEU) has been particularly accurately presented as an instrument of implementation of directives by courts, along with the special role of courts of the last instance in using this procedure (Article 267 pt. 2 TFEU).

The third chapter, entitled Obowiqzki implementacyjne sąów wynikajace $z$ modelu implementacji sensu stricto (Implementation obligations of courts stemming from the implementation model sensu stricto), presents the general obligations of Member States (national authorities) related to the normative aspect of the requirement to implement EU directives.

The obligations of national courts related to the implementation of directives are the subject of analysis, documented with a wealth of court case law, in chapter four, which is entitled Implementacja dyrektyw przez wykładnię przepisów krajowych (Implementation of directives by interpretation of national provisions) as well as chapter five: Implementacja dyrektyw przez stosowanie bezpośrednio skutecznych przepisów (Implementation of directives by application of directly effective provisions). Step-by-step, the author examines the grounds and conditions for the emergence of an obligation of pro-directive interpretation as a measure for the implementation of directives. The considerations in the book also refer to methods of interpreting national regulations that implement directives, starting from a linguistic to systemic and functional interpretation, as well as the limits of this constructed interpretation in the form of: prohibition of contra legem interpretation and the prohibition of deteriorating the legal situation of individuals. The analysis also encompasses the influence of a pro-directive interpretation of legal provisions by the court on its choice of the normative grounds for issuing a decision in a given case. Having discussed the construction of the direct effect of directive provisions, the author goes on to analyse the direct effect of directive provisions as providing normative grounds for the decision of a court adjudicating in an individual case. In this aspect of the considerations, directly effective provisions of a directive have been presented as: direct grounds for a court decision or indirect grounds for such a decision. Among the provisions of directives which may constitute indirect normative grounds for court decisions, the author identifies the following issues: 1) review of the legality of a decision issued by a national authority implementing the directive; 2 ) review of the application of the margin of discretionary power; 3 ) national 
technical provisions incompliant with the law in a situation where there is a dispute between authorities and 4) ineffective provisions of civil-law contracts infringing the directive.

In the last chapter, entitled Stosowanie prawa unijnego z urzędu jako szczególny przejaw sqadowej implementacji dyrektyw (Application of EU law ex officio as a special case of judicial implementation of directives), the subject of the analysis is the EU standard related to the obligation to apply provisions of EU directives by national courts motu proprio. Analysing the EU standard in this aspect, the author is quite right to begin from the principle of procedural autonomy and then proceed to discuss the consequences which the conditions of equivalence and effectiveness entail for EU law application ex officio. Subsequently, stating the absence, in principle, of an obligation, stemming solely from EU law, of national courts to act of their own motion, the author points out two important exceptions, which are the obligation of national courts to act ex officio for the protection of public policy regulations and for the protection of the consumer as the weaker party in a legal relationship.

The monograph's final conclusions comprise a summary of the most important findings of the analysis, corroborating the initial thesis that national courts are the organs of Member States which are obliged to implement directives in the course of exercising their powers, granted to them under national law, related to the application of national provisions falling within the scope of directive regulations.

Domańska's monograph, Implementacja dyrektyw unijnych przez sądy krajowe, Warszawa 2014, is a book well worth recommending particularly to those who seek an in-depth analysis of the problems of the application of EU law by the courts. The author's comprehensive discussion of the specific problems appearing in court jurisprudence deserves special attention, all the more so as it has been documented with an adequately selected case law of Polish courts of various levels. Owing to the above, the publication may be of interest for a wide circle of readers: judges, representatives of parties in litigation and theoreticians of law alike. 